\title{
Collision Tumors of the Gastrointestinal Tract: A Systematic Review of the Literature
}

\author{
DIMITRIOS SCHIZAS ${ }^{1}$, IOANNIS KATSAROS ${ }^{1}$, ADAMANTIOS MICHALINOS $^{1}$, \\ CHRISTOS DAMASKOS ${ }^{2}$, NIKOLAOS GARMPIS ${ }^{2}$, VASILEIA NTOMI ${ }^{3}$, \\ GEORGE AGROGIANNIS ${ }^{4}$, SPYRIDON STERGIOPOULOS ${ }^{5}$ and ALEXANDRA K. TSAROUCHA ${ }^{6}$ \\ ${ }^{1}$ First Department of Surgery, and ${ }^{2}$ Second Department of Propedeutic Surgery, \\ Laiko General Hospital, Medical School, National and Kapodistrian University of Athens, Athens, Greece; \\ ${ }^{3}$ Third Department of Surgery, National and Kapodistrian University of Athens, \\ Attikon University Hopsital, Athens, Greece; \\ ${ }^{4}$ First Department of Pathology, National and Kapodistrian University of Athens, Athens, Greece; \\ ${ }^{5}$ First Propedeutic Department of Surgery, Hippocration General Hospital, \\ National and Kapodistrian University of Athens, Athens, Greece; \\ ${ }^{6}$ Second Department of Surgery and Laboratory of Experimental Surgery, \\ Faculty of Medicine, Democritus University of Thrace, Alexandroupolis, Greece
}

\begin{abstract}
Background/Aim: Collision tumors are rare neoplasms which consist of two or more distinct neoplasms that develop adjacent to one another and coexist with no or minimal intermingling between them. Their diagnosis is often incidental and their behavior remains widely unknown. Several theories have been proposed regarding their pathogenesis. The objective of this study was the evaluation of current evidence on collision tumors of the gastrointestinal tract regarding their pathology, biological behavior and treatment approach. Materials and Methods: The PubMed and Cochrane bibliographical databases were searched from January 1997 to July 2018 (last search: July 5th, 2018) for studies reporting on collision tumors of the gastrointestinal tract that also included a therapeutic approach. Results: Forty-seven studies reporting on collision tumors of the gastrointestinal tract were identified. They reported collectively on 53 cases (43 males, 10 females) with collision
\end{abstract}

This article is freely accessible online.

Correspondence to: Dr Christos Damaskos, MD, MSc, Ph.D., Second Department of Propedeutic Surgery, Laiko General Hospital, Medical School, National and Kapodistrian University of Athens, 17 Agiou Thoma Street, Athens, 11527, Athens, Greece. Tel: +30 6948467790,e-mail: x_damaskos@yahoo.gr

Key Words: Collision tumors, rare tumors, gastrointestinal tract, esophagus, stomach, small intestine, large intestine, systematic review. tumors of the esophagus, stomach, small intestine and large intestine. The vast majority (96.2\%) of tumors consisted of two distinct histological components and only two cases involved a greater number of histological subtypes. Fifty-one patients underwent a surgical or endoscopic tumor resection, accompanied in 22 cases by adjuvant or neoadjuvant therapy. The remaining two patients underwent palliative operations. In total, three patients experienced immediate postoperative complications. Conclusion: Collision tumors of the gastrointestinal tract, despite their rare nature, constitute a quite interesting field of study. This review offers a thorough insight into the clinicopathological characteristics and biological behavior of these rare tumors.

Collision tumors (CTs) are composed of two neighboring independent neoplasms that coexist with no, or minimal intermingling between them (1-5). They are extremely rare and are usually found randomly during pathological evaluation of surgically excised specimens (3). They are more frequently encountered in the crania, lung, gastroesophageal junction, liver, rectum, bladder and uterus (6-8). Taking into account the rare nature of CTs, their behavior and treatment options remain a largely uninvestigated topic, with the only available data originating from case reports and small case series.

CTs belong to a large family of mixed neoplasms consisting of two or more cell populations (9). This category also includes composite tumors, carcinosarcomas and amphicrine tumors. Despite the existence of several diagnostic criteria, sometimes the differences between these 
Table I. Detailed characteristics of included cases.

\begin{tabular}{|c|c|c|c|c|c|}
\hline Site & $\begin{array}{l}\text { Number } \\
\text { of cases }\end{array}$ & $\begin{array}{l}\text { Males } \\
\mathrm{N}(\%)\end{array}$ & $\begin{array}{c}\text { Mean age } \pm S D \\
\text { years }\end{array}$ & $\begin{array}{l}\text { Location, } \\
\mathrm{N}(\%)\end{array}$ & $\begin{array}{c}\text { Treatment, } \\
\mathrm{N}(\%)\end{array}$ \\
\hline Esophagus & 17 & $15(88.2 \%)$ & $61.29 \pm 6.68$ & $\begin{array}{r}\text { Lower: } 9(52.9 \%) \\
\text { Middle: } 7(41.2 \%) \\
\text { Upper: } 1(5.9 \%)\end{array}$ & $\begin{array}{c}\text { Total esophagectomy: } 7(41.2 \%) \\
\text { Subtotal esophagectomy: } 9(52.9 \%) \\
\text { Esophageal bypass: } 1(5.9 \%)\end{array}$ \\
\hline Stomach & 20 & $15(75 \%)$ & $65 \pm 16.82$ & $\begin{array}{c}\text { Body: } 12(60 \%) \\
\text { Cardia: } 5(25 \%) \\
\text { Fundus: } 1(5 \%) \\
\text { Fundus-body juncture: } 1(5 \%) \\
\text { Whipple remnant: } 1(5 \%)\end{array}$ & $\begin{array}{l}\text { Total gastrectomy: } 6(30 \%) \\
\text { Subtotal gastrectomy: } 12(60 \%) \\
\text { Endoscopic resection: } 1(5 \%) \\
\text { Palliative gastrojejunostomy: } 1(5 \%)\end{array}$ \\
\hline Small intestine & 2 & $2(100 \%)$ & $59 \pm 18.39$ & Duodenum: $2(100 \%)$ & Surgical resection: $2(100 \%)$ \\
\hline Large intestine & 14 & $11(78.6 \%)$ & $64.07 \pm 17.68$ & $\begin{array}{c}\text { Appendix: } 4(28.6 \%) \\
\text { Cecum: } 2(14.3 \%) \\
\text { Transverse colon: } 2(14.3 \%) \\
\text { Sigmoid colon: } 2(14.3 \%) \\
\text { Rectosigmoid colon: } 2(14.3 \%) \\
\text { Ascending colon: } 1(7.1 \%) \\
\text { Hepatic flexure: } 1(7.1 \%)\end{array}$ & Surgical resection: $14(100 \%)$ \\
\hline
\end{tabular}

types are minimal and it is difficult to distinguish between them $(1,10,11)$. This is why many researchers use all the above terms interchangeably.

The pathogenesis of CT is not widely investigated and remains a controversial issue. Some studies indicate that these neoplasms come from a common progenitor cell that afterwards differentiates into two cell types which maintain their own individual characteristics (11, 12). Another proposed theory is that malignant transformations and changes in the local microenvironment of an original tumor promote the development of a second distinct tumor adjacent to it (13). On the other hand, other researchers suggest that CTs develop due to the effect of a carcinogenic stimulus on two neighboring regions of mucosa resulting in coexistence of two distinct neoplasms that later collide and possibly expand into each other (14-16).

The aim of this article was to systematically review the current evidence of published studies reporting on CT of the gastrointestinal tract and evaluate their pathology, treatment options and biological behavior.

\section{Materials and Methods}

This systematic review was carried out in accordance with the Preferred Reporting Items for Systematic Reviews and Meta Analyses (PRISMA) guidelines (17). Eligible articles were identified by a search of PubMed and Cochrane bibliographical databases for the period from January 1997 to July 2018 (last search: July 5th, 2018). Two investigators (DS, IK) working independently executed a thorough search using the following key words in all possible combinations: "collision tumor", "composite tumor", "carcinosarcoma”, "amphicrine neoplasm”, "gastrointestinal tract", "esophagus", "stomach", "colon" and "intestine". In addition, all the references of relevant articles that our search retrieved were checked. Any disagreements were resolved by consensus agreement by a third reviewer (AM).

In this systematic review, all English-language articles of the past two decades reporting only on CT of the gastrointestinal tract that also received some kind of treatment were included. We defined CT as consisting of two or more neighboring independent neoplasms which had no intermingling between them. Articles not written in English, published more than 20 years ago, animal studies, studies not reporting data for each patient separately, and articles not reporting any kind of treatment were excluded from this systematic review.

Data were extracted regarding age, sex and symptoms of the patient, affected organ, specific location, pathology of the tumor and lymph node infiltration. Data were also collected concerning type of treatment, 30-day post treatment complications and mortality, as well as disease-free period, local recurrence time, time to occurrence of distant metastasis and time of death after treatment.

Furthermore, a statistical analysis of the outcomes was performed by tabulating and then analyzing them using IBM SPSS Statistics for Windows, Version 24.0. (IBM Corp. Armonk, NY, USA).

\section{Results}

The literature search yielded 1,233 articles. Forty-seven met our inclusion criteria (15 for esophagus, 18 for stomach, two for small intestine, 11 for large intestine and one case series for both stomach and large intestine) and were included in this systematic review. The trial flow diagram is shown in Figure 1. They reported collectively on 53 patients with CT of the gastrointestinal tract. Characteristics of all cases included are summarized in Table I.

More specifically, as far as esophageal CTs are concerned, 17 cases (15 men and two women) with a mean age of $61.29 \pm 6.68$ (mean, SD) years were collected. Their main symptoms included dysphagia, chest discomfort or pain and 


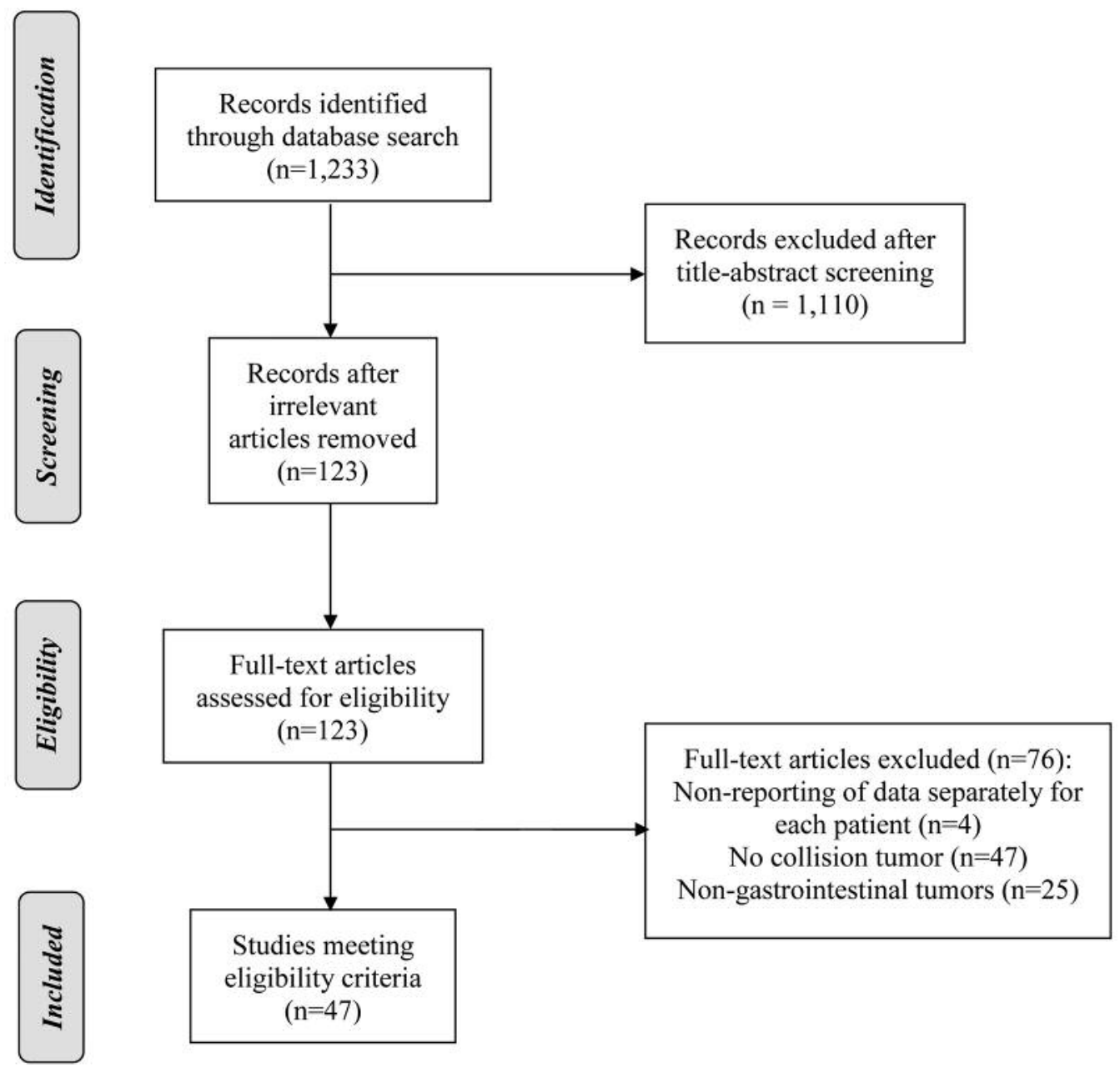

Figure 1. Trial flow diagram of this systematic review.

weigh loss. Only one patient had no symptoms. The majority of cases $(52.9 \%)$ were located at the lower third of the esophagus, $41.2 \%$ were located at the middle third and only one CT $(5.9 \%)$ was located at the upper third. The most common component of CT was squamous cell carcinoma, which was present at $82.4 \%$ of the cases, followed by adenocarcinoma, which was encountered in $35.3 \%$ of patients. Undifferentiated sarcoma and small cell carcinoma had a frequency of $29.4 \%$. Detailed pathology of all esophageal CTs is shown in Table II. Regional lymph nodes were infiltrated in $47.1 \%$ of the cases, originating mainly from the carcinomatous element, but there was no report of a collision infiltration pattern. All 17 patients were surgically treated. Nine underwent subtotal esophagectomy, seven underwent total esophagectomy and one patient had an esophageal bypass. Three patients received neoadjuvant therapy and nine received adjuvant therapy. No immediate postoperative complications or death were reported. The median disease-free period was 18 (range=6-72) months. Four patients had local recurrence or distant metastasis within 12 months following surgery. Finally, four patients died during the follow-up period, at a median of 12.5 (range $=8-17$ ) months .

With regards to the stomach, there were 20 patients $(15$ men and five women) with a mean \pm SD age of $65 \pm 16.82$ years. Their main symptomatology included epigastric discomfort or pain, dysphagia, anorexia and weigh loss. Twelve cases $(60 \%)$ were located at the body of the stomach, five $(25 \%)$ were located at the cardia and the remaining three cases were found at the fundus, fundus-body juncture and at the stomach remnant following a Whipple's operation respectively. Gastric adenocarcinoma was the commonest histological component, being present in $85 \%$ of the cases, followed by gastrointestinal stromal tumor, which was encountered in $30 \%$ of the cases. 
Table II. Detailed pathology of esophageal collision tumors.

\begin{tabular}{|c|c|c|c|c|c|c|c|c|c|c|c|c|c|}
\hline $\begin{array}{l}\text { Author } \\
\text { (Ref) }\end{array}$ & $\begin{array}{l}\text { Well- } \\
\text { differentiated } \\
\text { adeno- } \\
\text { carci- } \\
\text { noma }\end{array}$ & $\begin{array}{l}\text { Moderately } \\
\text { differentiated } \\
\text { adeno- } \\
\text { carci- } \\
\text { noma }\end{array}$ & $\begin{array}{l}\text { Poorly } \\
\text { cohesive } \\
\text { adeno- } \\
\text { carci- } \\
\text { noma }\end{array}$ & $\begin{array}{c}\text { Small } \\
\text { cell } \\
\text { carci- } \\
\text { noma }\end{array}$ & $\begin{array}{l}\text { Large } \\
\text { cell } \\
\text { carci- } \\
\text { noma }\end{array}$ & $\begin{array}{c}\text { Squamous } \\
\text { cell } \\
\text { carci- } \\
\text { noma }\end{array}$ & $\begin{array}{l}\text { Adenoid } \\
\text { cystic } \\
\text { carci- } \\
\text { noma }\end{array}$ & $\begin{array}{l}\text { Neuro- } \\
\text { endocrine } \\
\text { carci- } \\
\text { noma }\end{array}$ & GIST & $\begin{array}{c}\text { Un- } \\
\text { differentiated } \\
\text { sarcoma }\end{array}$ & $\begin{array}{l}\text { Leiomyo- } \\
\text { sarcoma }\end{array}$ & $\begin{array}{c}\text { Osteo } \\
\text { sarcoma }\end{array}$ & $\begin{array}{c}\text { Total } \\
\text { number of } \\
\text { histological } \\
\text { components }\end{array}$ \\
\hline $\begin{array}{l}\text { Schizas } \\
\text { et al. (21) }\end{array}$ & - & + & + & + & - & - & - & - & - & - & - & - & 3 \\
\hline $\begin{array}{l}\text { Yao } \\
\text { et al. (58) }\end{array}$ & - & - & - & - & - & + & - & - & - & - & + & - & 2 \\
\hline $\begin{array}{l}\text { Qian } \\
\text { et al. (59) }\end{array}$ & - & - & - & - & - & + & - & - & + & - & - & - & 2 \\
\hline $\begin{array}{l}\text { Wang } \\
\text { et al. (29) }\end{array}$ & - & - & - & + & - & + & - & - & - & - & - & - & 2 \\
\hline $\begin{array}{l}\text { Wang } \\
\text { et al. (29) }\end{array}$ & - & - & - & + & - & + & - & - & - & - & - & - & 2 \\
\hline $\begin{array}{l}\text { Wang } \\
\text { et al. (29) }\end{array}$ & - & - & - & - & - & + & + & - & - & - & - & - & 2 \\
\hline $\begin{array}{l}\text { Matsutani } \\
\text { et al. (22) }\end{array}$ & - & - & - & - & - & + & - & - & - & + & - & - & 2 \\
\hline $\begin{array}{l}\text { Adachi } \\
\text { et al. (35) }\end{array}$ & - & - & - & - & - & + & - & + & - & - & - & - & 2 \\
\hline $\begin{array}{l}\mathrm{Li} \\
\text { et al. (31) }\end{array}$ & - & - & - & + & - & + & - & - & - & - & - & - & 2 \\
\hline $\begin{array}{l}\text { Zhao } \\
\text { et al. }(60)\end{array}$ & - & - & - & - & - & + & - & - & - & + & - & - & 2 \\
\hline $\begin{array}{l}\text { Akagi } \\
\text { et al. (61) }\end{array}$ & - & - & - & - & - & + & - & - & - & + & - & - & 2 \\
\hline $\begin{array}{l}\text { Bibeau } \\
\text { et al. (27) }\end{array}$ & + & - & - & + & - & - & - & - & - & - & - & - & 2 \\
\hline $\begin{array}{l}\text { Sanada } \\
\text { et al. (33) }\end{array}$ & - & - & - & - & - & + & - & - & - & + & - & - & 2 \\
\hline $\begin{array}{l}\text { Iwaya } \\
\text { et al. (32) }\end{array}$ & - & - & - & - & - & + & - & - & - & - & - & + & 2 \\
\hline $\begin{array}{l}\text { Nakagawa } \\
\text { et al. (62) }\end{array}$ & + & - & - & - & - & + & - & - & - & - & - & - & 2 \\
\hline $\begin{array}{l}\text { Wilson } \\
\text { et al. (63) }\end{array}$ & + & - & - & - & + & - & - & - & - & - & - & - & 2 \\
\hline $\begin{array}{l}\text { Robertson } \\
\text { et al. (64) }\end{array}$ & + & - & - & - & - & + & - & + & - & + & - & - & 4 \\
\hline Total & $4(23.5 \%)$ & $1(5.9 \%)$ & $1(5.9 \%)$ & $5(29.4 \%$ & \%)1 (5.9 & $9 \%) 14(82$. & $4 \%) 1(5.9$ & $9 \%) 2(11.8$ & $\%) 1(5$ & $5.9 \%) 5(29.4 \%$ & $\%) 1(5.9 \%)$ & $1(5.9 \%)$ & 37 \\
\hline
\end{tabular}

GIST: Gastrointestinal stromal tumor.

Table III presents detailed pathology of each case. In 12 cases reported lymph nodes metastases were reported, with the majority of them arising from the adenocarcinoma component. Two of them presented a biphasic pattern of infiltration originating in both cases from gastric adenocarcinoma in combination with spindle cell sarcoma in one case and with lymphoma in the other case $(18,19)$. Eighteen CTs $(90 \%)$ were surgically resected, 12 patients underwent total gastrectomy and six patients had a subtotal gastrectomy. Furthermore, one CT was endoscopically resected and one patient underwent only palliative gastrojejunostomy due to the extended and invasive character of the tumor. Four patients received adjuvant therapy and one had neoadjuvant therapy. Three patients experienced postoperative complications and one died on the 24th postoperative day. Data for the disease-free period were only available for four patients and were 6, 18, 24 and 36 months following tumor resection. There were no data available for local recurrence. Two patients had distant metastases at 7 and 17 months following surgery and five patients died 3 to 32 months (median=7 months) postoperatively.

With regards to the small intestine, only two cases (both men) were retrieved. Patients were 46 and 72 years old. One experienced loss of appetite and the other one had jaundice. CT in one case was located at the ampulla of Vater and in the 


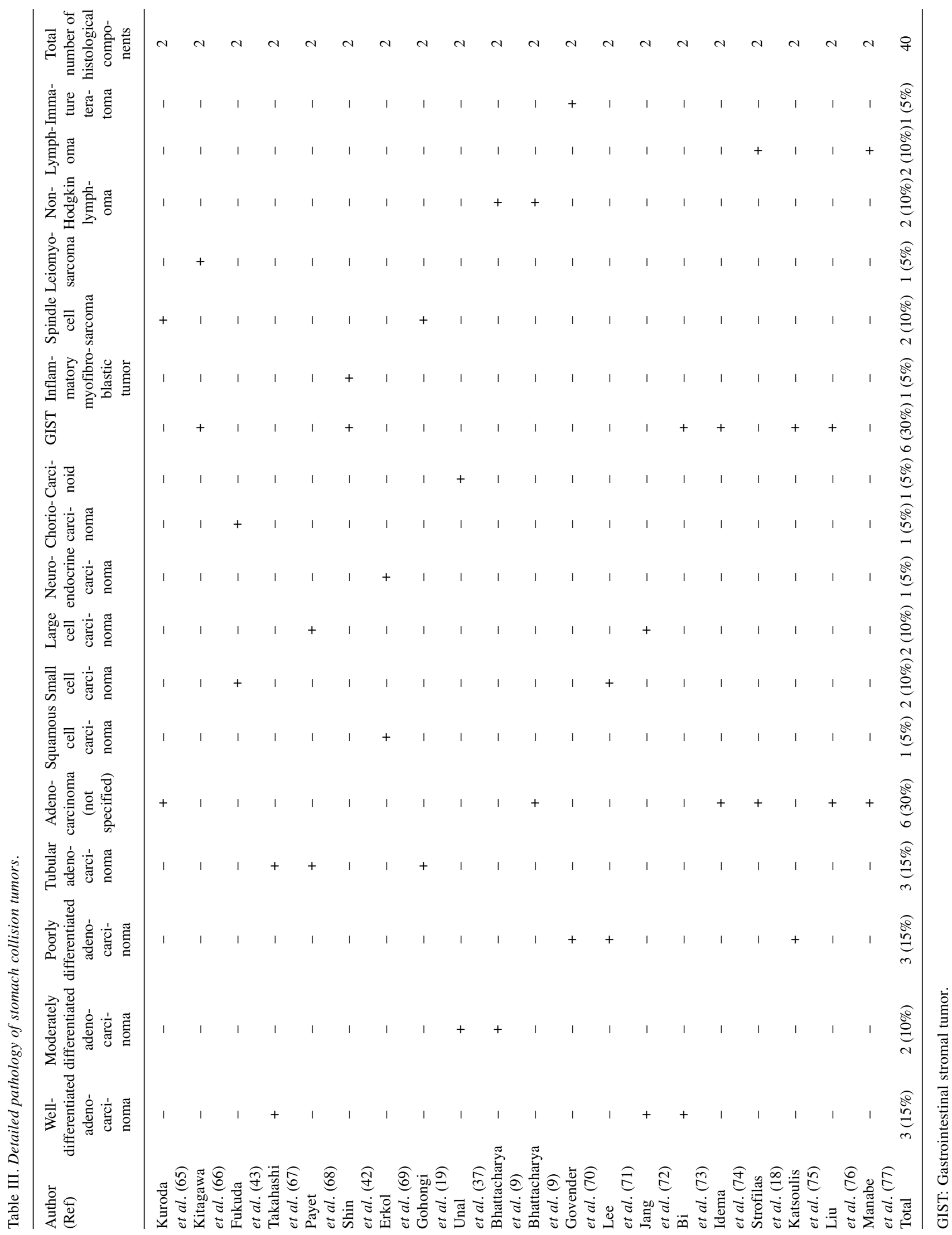


other at the duodenum on the opposite site from the ampulla of Vater. Both CTs consisted of tubular adenocarcinoma and spindle cell sarcoma and were surgically resected. One case had lymph node involvement, with only the adenocarcinoma component being present. One patient received adjuvant therapy and experienced no postoperative complications. This patient was disease-free at 9 months following surgery. There were no data available for the other patient.

Finally, as far as the large intestine is concerned, 14 cases (11 men and three women) were collected and they had a mean \pm SD age of $64.07 \pm 17.68$ years. Their main symptoms were abdominal pain, anorexia, nausea and vomiting. Two patients were asymptomatic. Four cases $(28.6 \%)$ were located at the appendix. CTs were found in the cecum, transverse colon, sigmoid colon and rectosigmoid juncture in two cases each. Additionally, one tumor was found at the ascending colon and another one at the hepatic flexure. The most common histological component was adenocarcinoma, which was present in $78.6 \%$ of the cases. Carcinoid followed in frequency and was present in $35.7 \%$ of the patients. Detailed histological data of the aforementioned CTs of the large intestine are shown in Table IV. Ten cases reported on lymph node infiltration, with intestinal adenocarcinoma being the leading histological element. One case presented a colliding pattern of infiltration from adenocarcinoma and B-cell lymphoma (20). All fourteen cases were surgically treated, seven of them $(50 \%)$ received adjuvant therapy and no patient received neoadjuvant therapy. No postoperative complications or deaths were reported. Three patients were disease-free at 14, 24 and 60 months after surgery. One patient had local recurrence at 36 months and one patient had distant metastases 6 months postoperatively. Two patients died at 6 and 8 months after surgery.

\section{Discussion}

CTs are rare neoplasms consisting of two or more distinct neoplasms that develop in juxtaposition to one another and which have no or only minimal intermingling between them $(3,5,21)$. Their preoperative diagnosis is often incidental, as they have no special radiological or clinical features and preoperative biopsy usually involves only one histological component of the tumor $(3,22-24)$. However, their presence significantly alters the biological behavior of the tumor and treatment options should be adjusted accordingly (2). It is reported that the effect of one histological component on the behavior of the other increases the complexity of the therapeutic approach $(25,26)$. Some studies suggest that treatment should aim at the more aggressive element of the CT $(27,28)$. Nonetheless, given their rare nature, no definitive guidelines are currently available. To our knowledge, this is the first systematic review of CTs of the gastrointestinal tract which included a treatment approach.

CTs of the esophagus are extremely rare and our literature search yielded only 17 cases published over the past two decades. The vast majority of the cases (75\%) developed in patients over 56 years old. Wang et al. suggested that CTs, like common esophageal cancer, appear more often in men, which was also the case in our study, with $88 \%$ of the cases developing in men $(29,30)$. Several researchers agreed that they are usually located at the lower third of the esophagus $(29,31,32)$. Our findings are in accordance with that statement, with $52.9 \%$ of the cases located at the distal third of the esophagus. The middle third was the second location in frequency, with $41.2 \%$ of the cases being located there. Similarly to common esophageal cancer, the most prominent symptoms include dysphagia and retrosternal discomfort or pain (33). Like common esophageal cancer, squamous cell carcinoma was present in the majority of cases $(82.4 \%)$, with alcohol consumption and tobacco use being the major risk factors $(34,35)$. Other commonly encountered histological types include adenocarcinoma (35.3\%), undifferentiated sarcoma (29.4\%) and small cell carcinoma (29.4\%). Esophagectomy (total or subtotal) is the optimal treatment option for these cases, but the unique nature of theses tumors requires a more aggressive oncological approach (21). All our cases were surgically treated, with the majority of them undergoing subtotal esophagectomy. Additionally, nine patients received adjuvant therapy and three patients received neoadjuvant therapy. Available data on postoperative course and follow up were extremely limited, but no immediate postoperative complication or death was recorded. The disease-free period ranged from 6 to 72 months and time to local recurrence or distant metastasis from 3 to 42 months. Four patients died 8 to 17 months following surgery.

Furthermore, CTs of the stomach are also a rare entity, with only 20 cases published during the past 20 years. Their time of development is similar to those of the esophagus, with $75 \%$ of the cases appearing in patients over 54 years old. These tumors appear more often in men $(75 \%$ at our study) similarly to gastric adenocarcinoma (36). Several studies agree that the majority of these tumors are located in the body of the stomach (37-39). Our findings are in accordance with these studies, with $60 \%$ of the tumors located at the body. The cardia was the second location in frequency, at $25 \%$ of the cases. The main symptoms of these tumors include epigastric pain or discomfort, nausea, vomiting, anorexia and weight loss, and are similar to those of other gastric cancer (40). Gastric adenocarcinomas are the most common histopathological type of gastric tumors and this was also the case in our study, where different types of adenocarcinoma were the most common component (85\%) (41). Gastrointestinal stromal tumor was also present in $30 \%$ of the cases. Gohondi et al. suggested that gastrectomy along with radiation therapy might be the optimal treatment option for gastric carcinosarcomas (19). The vast majority of the cases $(90 \%)$ in our review underwent gastrectomy (total or 


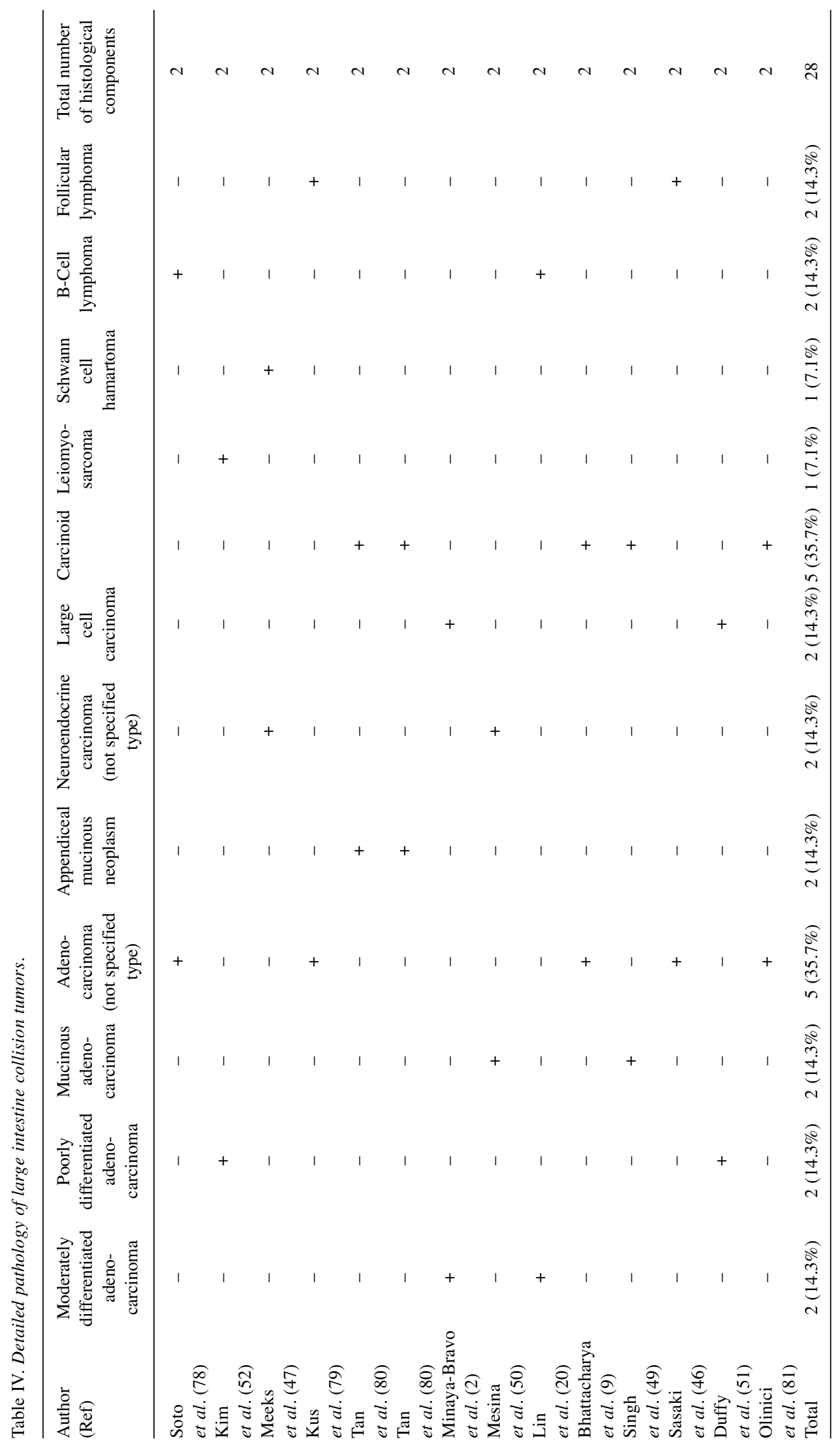


subtotal). On the other hand, only three patients received adjuvant therapy and only one had neoadjuvant therapy. Given their rare nature, it is challenging to determine the behavior of CTs, but it is suggested that they have a greater risk for metastasis (42). Moreover, in adenocarcinoid CT, their progression seems to depend on the glandular component (9). Available data on their behavior are too limited to be able to reach safe conclusions. However, it is noted that three patients had postoperative complications and one died on the 24th postoperative day due to multiple organ failure (43). The disease-free period ranged from 3 to 36 months. No data were available for local recurrence. Two patients developed metastases 7 and 17 months following surgery and five patients died 3 to 32 months after tumor resection.

Finally, CTs of the small and large intestine are also rare and our literature search yielded only 16 cases. Small intestine adenocarcinoma and colorectal cancer are more often encountered in men $(44,45)$. This was also the case for our study findings with $81.3 \%$ of the CTs appearing in men. Moreover, the vast majority (75\%) of the patients were over 52 years old. Both small intestine CTs were located at the duodenum. There is no prevailing location for the development of CT of the large intestine, as they can appear anywhere from the cecum to the rectum. However, our findings suggest that there is a slightly increased tendency for the appendix, where $28.6 \%$ of the cases were found. The majority of patients present with varied symptoms (46). Depending on the location of the $\mathrm{CT}$, these include abdominal pain, nausea, vomiting, weight loss and constipation (47). Most carcinomas of the duodenum are well- to moderately differentiated adenocarcinoma (48). Both the cases found in our study consisted of tubular adenocarcinoma and spindle cell sarcoma. Most frequent components of large intestine CT include adenocarcinoma and carcinoid $(49,50)$. Duffy et al. suggested that management options should be more aggressive concerning CT with major neuroendocrine components (51). Given their rare nature, CTs of the colon do not have standards for treatment and prognosis (52). All the patients in our study underwent surgical removal of their tumors. Additionally, $50 \%$ received adjuvant therapy, but none received neoadjuvant therapy. The prognosis of CT of the small and large intestine is debatable and they tend to have an aggressive behavior $(49,53)$. It is not yet clarified if their biological behavior depends on the larger or the more aggressive component of the $\mathrm{CT}$ (50). The available data on postoperative follow-up were once again limited. No postoperative complications or death were stated in the studies included here. The disease-free period ranged from 9 to 60 months, one patient had local recurrence at 36 months and one had distant metastases at 6 months. Two patients died, at 6 and 8 months after tumor removal.
Pathogenesis of CT is unknown. Several theories have been proposed, yet none of them is satisfactory (47). The oldest and most simplistic theory is accidental meeting of two neoplasms developing independently and finally colliding. This theory is adopted by older reports and offers no particular explanations for the collision pattern $(54,55)$. However, as the synchronous occurrence of distinct cancers is rare but has been documented, this theory cannot be completely refuted.

A different theory is the common carcinogen or field theory. According to this theory, a common carcinogen induces synchronous and close development of distinct neoplasms that finally collide. Such agents are Helicobacter pylori, Epstein-Barr virus and certain chemicals (18). This theory is very appealing for explanation of synchronous gastric cancers, as $\mathrm{H}$. pylori is known to induce both gastric adenocarcinoma and lymphoma, and $N$-methyl- $N$-nitro- $N$ nitrosoguanide both gastric adenocarcinoma and leimyosarcoma (10), yet it does not explain the collision pattern and is not applicable to other organs.

A third theory states that development of a tumor induces development of an adjacent one through secretion of potential carcinogens such as gastrin (56) or granulocyte colonystimulating factor (57). This theory lacks experimental data.

The aforementioned theories assume two different neoplasms that ultimately interact and form a collision pattern. Yet newer data indicate a common cell for CT that differentiates into two distinct types during tumorigenesis. Milne et al. performed p53 and loss of heterozygosity analysis in cell components of two collision and three composite tumors and proved that both the collision and the two composite neoplasms shared the same mutations (11). This indicates a common cell origin and differentiation at an early stage of tumorigenesis. Fukui $e t$ al. performed a similar study on neuroendocrine-gastric adenocarcinoma CT and had similar results (12). Furthermore, they found additional p53 mutations at distal parts of the tumor. The common cell origin theory well explains rare cases of lymph node metastases presenting a collision pattern (54).

Another interesting field of research which can critically affect the therapeutic approach of CT is the infiltration pattern of lymph nodes. The majority of cases have metastases deriving from only one of their histological elements. However, several studies reported a biphasic pattern of infiltration, where both components of the CT coexisted $(18-20,54,55)$. A possible explanation could be that metastasis took place before the final differentiation of the distinct histological subtypes (10). There are also cases in which each of the components metastasized to different lymph node groups $(29,31)$.

\section{Conclusion}

CT of the gastrointestinal tract represent a limited, yet quite interesting, field of research. Specific follow-up protocol 
needs to be addressed in order to define the optimal treatment options for these neoplasms. All clinicians should not only be aware of these rare entities, but are also encouraged to consistently report such cases in order to enhance the available literature, thereby enabling more solid conclusions to be drawn.

\section{References}

1 Spagnolo DV and Heenan PJ: Collision carcinoma at the esophagogastric junction: Report of two cases. Cancer 46: 2702$2708,1980$.

2 Minaya-Bravo AM, Garcia Mahillo JC, Mendoza Moreno F, Noguelares Fraguas F and Granell J: Large cell neuroendocrine - Adenocarcinona mixed tumour of colon: Collision tumour with peculiar behaviour. What do we know about these tumours? Ann Med Surg 4: 399-403, 2015.

3 Ng WK, Lam KY, Chan AC and Kwong YL: Collision tumour of the oesophagus: a challenge for histological diagnosis. JClin Pathol 49: 524-526, 1996.

4 Klaase JM, Hulscher JB, Offerhaus GJ, ten Kate FJ, Obertop H and van Lanschot JJ: Surgery for unusual histopathologic variants of esophageal neoplasms: a report of 23 cases with emphasis on histopathologic characteristics. Ann Surg Oncol 10: 261-267, 2003.

5 Majmudar B, Dillard R and Susann PW: Collision carcinoma of the gastric cardia. Hum Pathol 9: 471-473, 1978.

6 Syed S, Karambizi DI, Baker A, Groh DM and Toms SA: A comparative report on intracranial tumor-to-tumor metastasis and collision tumors. World Neurosurg 116: 454-463, 2018.

7 Bhangoo MS, Zhou JY, Ali SM, Madison R, Schrock AB and Costantini C: Objective response to mTOR inhibition in a metastatic collision tumor of the liver composed of melanoma and adenocarcinoma with TSC1 loss: A case report. BMC Cancer 17: 197, 2017.

8 Montironi R, Santoni M, Goteri G, Mazzucchelli R, LopezBeltran A, Cheng L and Scarpelli M: Pseudocarcinomatous hyperplasia associated with primary lymphoma in the urinary bladder: a case report. Hum Pathol 46: 1040-1044, 2015.

9 Bhattacharya A, Saha R, Biswas J, Biswas J and Ghosh B: Collision tumors in the gastrointestinal tract: A rare case series. Int Med Case Rep J 5: 73-77, 2012.

10 Michalinos A, Constantinidou A and Kontos M: Gastric collision tumors: An insight into their origin and clinical significance. Gastroenterol Res Pract 2015: 314158, 2015.

11 Milne AN, Carvalho R, van Rees BP, van Lanschot JJ, Offerhaus GJ and Weterman MA: Do collision tumors of the gastroesophageal junction exist? A molecular analysis. Am J Surg Pathol 28: 1492-1498, 2004.

12 Fukui H, Takada M, Chiba T, Kashiwagi R, Sakane M, Tabata F, Kuroda Y, Ueda Y, Kawamata H, Imura J and Fujimori T: Concurrent occurrence of gastric adenocarcinoma and duodenal neuroendocrine cell carcinoma: A composite tumour or collision tumours? Gut 48: 853-856, 2001.

13 Brahmania M, Kanthan CS and Kanthan R: Collision tumor of the colon-colonic adenocarcinoma and ovarian granulosa cell tumor. World J Surg Oncol 5: 118, 2007.

14 Dodge OG: Gastro-oesophageal carcinoma of mixed histological type. J Pathol Bacteriol 81: 459-471, 1961.
15 Purdy $S$ and Gaffney EF: Ultrastructural and immunocytochemical definition of component neoplasms in an unusual gastro-oesophageal collision tumour. Histopathology 10: 525$534,1986$.

16 Geisinger KR, Dabbs DJ and Marshall RB: Malignant mixed mullerian tumors. An ultrastructural and immunohistochemical analysis with histogenetic considerations. Cancer 59: 1781-1790, 1987.

17 Liberati A, Altman DG, Tetzlaff J, Mulrow C, Gøtzsche PC, Ioannidis JP, Clarke M, Devereaux PJ, Kleijnen J and Moher D: The PRISMA statement for reporting systematic reviews and meta-analyses of studies that evaluate health care interventions: Explanation and elaboration. PLoS Med 6: e1000100, 2009.

18 Strofilas A, Dalianoudis IG, Lagoudianakis EE, Genetzakis M, Tsekouras D, Chrysikos J, Koronakis N, Katergiannakis V and Manouras A: Collision tumour of the stomach with a cancer to cancer metastasis: A case report. Cases J 1: 63, 2008.

19 Gohongi T, Iida H, Gunji N, Orii K and Ogata T: Postsurgical radiation therapy for gastric carcinosarcoma with c-KIT expression: A case report. World J Gastroenterol 21: 2830-2835, 2015.

20 Lin HH, Jiang JK and Lin JK: Collision tumor of low-grade Bcell lymphoma and adenocarcinoma with tuberculosis in the colon: A case report and literature review. World J Surg Oncol 12: 147, 2014.

21 Schizas D, Michalinos A, Alexandrou P, Moris D, Baliou E, Tsilimigras D, Throupis $\mathrm{T}$ and Liakakos T: A unique tripartite collision tumor of the esophagus: A case report. Medicine 96: e8784, 2017.

22 Matsutani T, Nomura T, Hagiwara N, Yoshida H, Yokoyama T, Katayama H, Hosone M, Matsuda A and Uchida E: A case of carcinosarcoma of the esophagus detected on fluorodeoxyglucose positron-emission tomography. J Nippon Med Sch 81: 401-405, 2014.

23 González LM, Sanz-Esponera J, Saez C, Alvarez T, Sierra E and Sanz-Ortega J: Case report: esophageal collision tumor (oat cell carcinoma and adenocarcinoma) in Barrett's esophagus: Immunohistochemical, electron microscopy and $\mathrm{LOH}$ analysis. Histol Histopathol 18: 1-5, 2003.

24 Karkouche R, Bachet JB, Sandrini J, Mitry E, Penna C, Côté JF, Blons H, Penault-Llorca F, Rougier P, Saint André JP and Emile JF: Colorectal neuroendocrine carcinomas and adenocarcinomas share oncogenic pathways. A clinico-pathologic study of 12 cases. Eur J Gastroenterol Hepatol 24: 1430-1437, 2012.

25 Yoshimoto T, Kobayashi S, Kanetaka K, Kobayashi K, Nagata Y, Morita M, Isagawa Y, Kinoshita N, Takatsuki M and Eguchi S: Preoperative chemotherapy with docetaxel, cisplatin, and 5fluorouracil for locally advanced esophageal carcinosarcoma: A case report and review of the literature. Surg Case Rep 4: 18, 2018.

26 Genovese F, Becchina G, Nagar C, Ottoveggio G, Giacalone B, Scaglione G, Varriale E and Tralongo V: Primary diffuse large B-cell lymphoma developing within a rectal tubular adenoma with low-grade dysplasia: A case report. J Med Case Rep 8: 103, 2014.

27 Bibeau F, Chateau MC, Guiu M, Assenat E, Azria D, Lavaill R, Ychou M and Boissière-Michot F: Small cell carcinoma with concomitant adenocarcinoma arising in a Barrett's oesophagus: Report of a case with a favourable behaviour. Virchows Arch 452: 103-107, 2008. 
28 Nishimaki T, Nakagawa S, Aizawa K, Suzuki T, Hatakeyama K and Watanabe $\mathrm{H}$ : Composite tumor of the esophagus with tripartite differentiation. Dig Dis Sci 42: 1041-1046, 1997.

29 Wang L, Zhan C, Ma J, Shi Y and Wang Q: Collision tumor of esophagus: Report of three cases. Ann Thorac Surg 97: 10751077, 2014.

30 Rutegård $\mathrm{M}$, Lagergren $\mathrm{P}$, Nordenstedt $\mathrm{H}$ and Lagergren $\mathrm{J}$ : Oesophageal adenocarcinoma: The new epidemic in men? Maturitas 69: 244-248, 2011.

31 Li J, Chen X, Shen Y, Hou Y, Zhang S, Wang H, Feng M, Tan L, Wang $Q$ and Zeng Z: A rare collision tumor of squamous carcinoma and small cell carcinoma in esophagus involved with separate lymph nodes: A case report. J Thorac Dis 5: E203-206, 2013.

32 Iwaya T, Maesawa C, Uesugi N, Kimura T, Ogasawara S, Ikeda K, Kimura Y, Mitomo S, Ishida K, Sato N, Saito K and Masuda T: True carcinosarcoma of the esophagus. Dis Esophagus 19: 4852, 2006.

33 Sanada Y, Hihara J, Yoshida K and Yamaguchi Y: Esophageal carcinosarcoma with intramural metastasis. Dis Esophagus 19: 119-131, 2006.

34 Prabhu A, Obi KO and Rubenstein JH: The synergistic effects of alcohol and tobacco consumption on the risk of esophageal squamous cell carcinoma: A meta-analysis. Am J Gastroenterol 109: 822-827, 2014.

35 Adachi K, Tateno Y and Okada H: An esophageal collision tumor. Clin Gastroenterol Hepatol 12: e17-18, 2014.

36 Parkin DM, Bray F, Ferlay J and Pisani P: Global cancer statistics, 2002. CA Cancer J Clin 55: 74-108, 2005.

37 Unal B, Elpek GO, Gelen T, Gürkan A and Yildirim B: Gastric collision tumor: Case report of a rare adenocarcinoma and a typical carcinoid tumor. Oncol Lett 6: 212-214, 2013.

38 Morishita Y, Tanaka T, Kato K, Kawamori T, Amano K, Funato $\mathrm{T}$, Tarao $\mathrm{M}$ and Mori $\mathrm{H}$ : Gastric collision tumor (carcinoid and adenocarcinoma) with gastritis cystica profunda. Arch Pathol Lab Med 115: 1006-1010, 1991.

39 Mróz A, Kiedrowski M, Malinowska M and Sopyło R: Collision tumour of the stomach--adenocarcinoma and neuroendocrine carcinoma: Case report and review of the literature. Pol J Pathol 60: 94-97, 2009.

40 Maconi G, Manes $\mathrm{G}$ and Porro GB: Role of symptoms in diagnosis and outcome of gastric cancer. World J Gastroenterol 14: 1149-1155, 2008

41 Modlin IM, Lye KD and Kidd M: Carcinoid tumors of the stomach. Surg Oncol 12: 153-172, 2003.

42 Shin HC, Gu MJ, Kim SW, Kim JW and Choi JH: Coexistence of gastrointestinal stromal tumor and inflammatory myofibroblastic tumor of the stomach presenting as a collision tumor: First case report and literature review. Diagn Pathol 10: 181, 2015.

43 Fukuda S, Fujiwara Y, Wakasa T, Inoue K, Kitani K, Ishikawa $\mathrm{H}$, Tsujie M, Yukawa M, Ohta Y and Inoue M: Collision tumor of choriocarcinoma and small cell carcinoma of the stomach: A case report. Int J Surg Case Rep 37: 216-220, 2017.

44 Murphy G, Devesa SS, Cross AJ, Inskip PD, McGlynn KA and Cook MB: Sex disparities in colorectal cancer incidence by anatomic subsite, race and age. Int J Cancer 128: 1668-1675, 2011.

45 Delaunoit T, Neczyporenko F, Limburg PJ and Erlichman C: Pathogenesis and risk factors of small bowel adenocarcinoma: A colorectal cancer sibling? Am J Gastroenterol 100: 703-710, 2005 .
46 Sasaki S, Hatanaka K, Sahara N, Uekusa T, Hirayama K, Shirahata A and Ishimaru M: Collision tumor of primary malignant lymphoma and adenocarcinoma in the colon: report of a case. Surg Today 40: 975-981, 2010.

47 Meeks MW, Grace S, Chen Y, Petterchak J, Bolesta E, Zhou Y and Lai JP: Synchronous quadruple primary neoplasms: Colon adenocarcinoma, collision tumor of neuroendocrine tumor and schwann cell hamartoma and sessile serrated adenoma of the appendix. Anticancer Res 36: 4307-4311, 2016.

48 Sunagawa H, Inamine S, Watanabe M, Kawakami K, Toyama T, Zaha H, Yonaha T, Ohta M, Oshiro N, Takeshima M and Uchima $\mathrm{H}$ : Carcinosarcoma of the duodenum: Report of a case. Surg Today 39: 892-896, 2009.

49 Singh NG, Mannan AA, Kahvic M and Nur AM: Mixed adenocarcinoma-carcinoid (collision tumor) of the appendix. Med Princ Pract 20: 384-386, 2011.

50 Meşină C, Vasile I, Ciobanu D, Calotă F, Gruia CL, Streba L, Mogoantă SŞ, Pârvănescu H, Georgescu CV and Tarniţă DN: Collision tumor of recto-sigmoidian junction- case presentation. Rom J Morphol Embryol 55(2 Suppl): 643-647, 2014.

51 Duffy A, Shia J, Klimstra D, Temple L and O'Reilly EM: Collision tumor of the large bowel in the context of advanced pregnancy and ulcerative colitis. Clin Colorectal Cancer 7: 402405, 2008.

52 Kim VM, Goicochea L and Fang SH: Case report: Collision tumour of colon leiomyosarcoma and adenocarcinoma. J Clin Diagn Res 10: PD03-04, 2016.

53 Sasajima K, Taniguchi Y, Morino K, Yamashita K, Onda M, Hao $\mathrm{K}$ and Takubo K: Rapid growth of a pseudosarcoma of the esophagus. J Clin Gastroenterol 10: 533-536, 1988.

54 Jernstrom P and Murray GC: Synchronous double primary lymphosarcoma and adenosarcoma (collision tumor) of the stomach with cancer-to-cancer metastasis. Cancer 19: 60-66, 1966.

55 Parks TG: Malignant carcinoid and adenocarcinoma of the stomach. Br J Surg 57: 377-379, 1970.

56 de Leval L, Hardy N, Deprez M, Delwaide J, Belaïche J and Boniver J: Gastric collision between a papillotubular adenocarcinoma and a gastrinoma in a patient with ZollingerEllison syndrome. Virchows Arch 441: 462-465, 2002.

57 Komatsu D, Sakurai M, Nakafuji H, Koide N, Morishita H and Nakamura T: Granulocyte colony stimulating factor-producing collision tumor of the gastric cardia. J Gastroenterol 38: 10131015, 2003.

58 Yao B, Guan S, Huang X, Su P, Song Q and Cheng Y: A collision tumor of esophagus. Int J Clin Exp Pathol 8: 1514315146, 2015.

59 Qian T, Gao F, Chen MZ, Meng FH, Li XJ, Liu YJ and Yin HB: Collision tumor of the esophagus: report of a case with mixed squamous cell carcinoma and gastrointestinal stromal tumor. Int J Clin Exp Pathol 7: 1206-1211, 2014.

60 Zhao S, Xue Q, Ye B, Lu H, He J and Zhao H: Synchronous primary carcinosarcoma and adenosquamous carcinoma of the esophagus. Ann Thorac Surg 91: 926-928, 2011.

61 Akagi I, Miyashita M, Makino H, Nomura T, Ohkawa K and Tajiri T: So-called carcinosarcoma of the esophagus: report of a case. J Nippon Med Sch 75: 171-174, 2008.

62 Nakagawa S, Nishimaki T, Kanda T, Suzuki T and Hatakeyama $\mathrm{K}$ : Composite tumor with papillary adenocarcinoma and squamous cell carcinoma of the esophagus: report of a case. Surg Today 30: 364-367, 2000. 
63 Wilson CI, Summerall J, Willis I, Lubin J and Inchausti BC: Esophageal collision tumor (Large cell neuroendocrine carcinoma and papillary carcinoma) arising in a Barrett esophagus. Arch Pathol Lab Med 124: 411-415, 2000.

64 Robertson NJ, Rahamim J and Smith ME: Carcinosarcoma of the oesophagus showing neuroendocrine, squamous and glandular differentiation. Histopathology 31: 263-266, 1997.

65 Kuroda H, Saito H, Kono Y, Murakami Y, Shishido Y, Matsunaga T, Fukumoto Y, Osaki T, Ashida K, Nosaka K, Umekita Y and Fujiwara Y: Carcinosarcoma of stomach confined to the mucosa. Yonago Acta Med 60: 246-250, 2017.

66 Kitagawa H, Kaneko M, Kano M, Ibuki Y, Amatya VJ, Takeshima Y, Hirabayashi $\mathrm{N}$ and Hirota S: Coexistence of gastrointestinal stromal tumor and leiomyosarcoma of the stomach presenting as a collision tumor: A case report and review of literature. Pathol Int 68: 313-317, 2018.

67 Takahashi K, Fujiya M, Ichihara S, Moriichi K and Okumura T: Inverted gastric adenocarcinoma of fundic gland mucosa type colliding with well differentiated adenocarcinoma: A case report. Medicine (Baltimore) 96: e7080, 2017.

68 Payet E, Pilco PI, Montes J, Cordero-Morales A, Savitzky MJ and Stenning-Persivale K: Collision tumour of large-cell neuroendocrine carcinoma and adenocarcinoma in the stomach: A case report. Ecancermedicalscience 10: 616, 2016.

69 Erkol B, Tilki M, Comunoğlu N, Öven Ustaalığlu BB, Aker F, Sürmelioğlu A, Telli F, Gemici C, Kılıçoğlu ZG and Yeşil A: Neuroendocrine/squamous gastric collision tumor: A rare entity. Turk J Gastroenterol 25(Suppl 1): 282-283, 2014.

70 Govender D, Serra S and Chetty R: Collision tumor of the stomach: an unusual combination of adenocarcinoma and immature "neuroepitheliomatous" teratoma. Int J Surg Pathol 20: 507-510, 2012.

71 Lee HH, Jung CK, Jung ES, Song KY, Jeon HM and Park CH: Mixed exocrine and endocrine carcinoma in the stomach: a case report. J Gastric Cancer 11: 122-125, 2011.

72 Jang KY, Pilco PI, Montes J, Cordero-Morales A, Savitzky MJ and Stenning-Persivale K: Gastric collision tumor of large cell neuroendocrine carcinoma and adenocarcinoma - a case report. Pathol Res Pract 206: 387-390, 2010.
73 Bi R, Sheng W and Wang J: Collision tumor of the stomach: Gastric adenocarcinoma intermixed with gastrointestinal stromal tumor. Pathol Int 59: 880-883, 2009.

74 Idema DL, Daryanani D, Sterk LM and Klaase JM: Collision tumor of the stomach: A case of an adenocarcinoma and a gastrointestinal stromal tumor. Case Rep Gastroenterol 2: 456-460, 2008.

75 Katsoulis IE, Bossi M, Richman PI and Livingstone JI: Collision of adenocarcinoma and gastrointestinal stromal tumour (GIST) in the stomach: report of a case. Int Semin Surg Oncol 4: 2, 2007.

76 Liu SW, Chen GH and Hsieh PP: Collision tumor of the stomach: a case report of mixed gastrointestinal stromal tumor and adenocarcinoma. J Clin Gastroenterol 35: 332-334, 2002.

77 Manabe T, Nishihara K, Kurokawa Y, Hattanda Y, Toyoshima S, Takeda $\mathrm{S}$ and Abe R: A collision tumor composed of adenocarcinoma and malignant lymphoma in the remnant stomach after pancreatoduodenectomy: report of a case. Surg Today 31: 450-453, 2001.

78 Soto AR, Vazquez EG, Grigg-Gutierrez NM, MagnoPagatzaurtundua P, Cáceres W and Toro DH: Conundrum of a large bowel neoplasm: Collision tumor. ACG Case Rep J 5: e13, 2018.

79 Kus T, Aktas G, Kalender ME, Sari I, Ulker E and Camci C: Collision tumor consisting of primary follicular lymphoma and adenocarcinoma in the cecum: A case report and literature review. Oncol Lett 11: 2801-2805, 2016.

80 Tan HL, Tan GH and Teo M: Two rare cases of appendiceal collision tumours involving an appendiceal mucinous neoplasm and carcinoid. BMJ Case Rep 2016: bcr2015213938, 2016.

81 Olinici CD, Domşa I and Crişan D: Collision adenocarcinoma-carcinoid tumor of the colon. Case report and review of the literature. Rom J Morphol Embryol 48: 75-78, 2007.
Received September 4, 2018

Revised September 25, 2018

Accepted October 1, 2018 